\title{
Reducing the Soluble Oxalate and Phytic Acid in Taro Corm Chips by Soaking in Calcium Salt Solutions
}

\begin{abstract}
Samaa, M. Saleh
Food Science Dept., Fac. of Agric. (Saba Basha), Alexandria University, Alexandria, Egypt.

Received: 16 July, 2019

Revised: 1 December, 2019

Accepted: 15 December, 2019

ABSTRACT

Taro (Colocasia esculentum (L)) corm is one of the most nutritious and easily digested foods, but unfortunately contains anti-nutritional factors such as oxalates and phytic acid.The oxalates which can lead to risks of kidney stones, while phytic acid reduces bioavailability of minerals. Therefore, the anti-nutritional factors must be removed or decreased before utilization of corm as food by carrying out chemical or physical process such as soaking, boiling, fermentation or cooking. So, the incorporation of chemical and physical methods is expected to be a very efficient ways of processing. The aim of the present study was to investigate the effect of using calcium salts such as calcium carbonate, calcium chloride and calcium sulphate at different concentrations $(0,1,3,5 \% \mathrm{w} / \mathrm{v})$ during soaking periods for (30 and $60 \mathrm{~min}$ ) on reducing soluble oxalate and phytic acid in taro corm chips. The experimental results indicated that the optimal conditions were soaking taro corm chips in calcium chloride solution at concentration of $5 \%$ for 60 min., since the content of both soluble oxalate and phytic acid were found to decrease from 294.3 to $35.1 \mathrm{mg} / 100 \mathrm{~g}$ and from 161.16 to $133.68 \mathrm{mg} / 100 \mathrm{~g}$ respectively. Calcium carbonate was the lowest effective additive.
\end{abstract}

Keywords: Taro corm chips, soluble oxalate, phytic acid, calcium salts, pH.

\section{INTRODUCTION}

Taro or cocoyam is the common name for edible corm belongs to Araceae family which plays an important role in the food security in many developing countries and many regions of subtropics and tropics of the world. The term taro is usually used to indicate Colocasia esculenta(L.) (Matthew, 2004).

Nutritionally, the taro corms are considered source of starch easily digestible, also containsignificant levels of protein, thiamine, riboflavin, niacin and vitamin C (John et al., 2007). Generally, the nutritional value of food depends on their contents of nutrients, nutrient utilization and the absence or presence of anti-nutritional factors and harmfully factors (Alcantara et al., 2013). Antinutritional factors play an important role to reduce nutrient utilization and/or food intake.

Taro like most foods of plants contains several anti-nutritional factors for example oxalates, phytates, amylase and trypsin inhibitors, tannins and cyanide. So, it is prefer to process taro before consumption as raw material. (Bhandari \& Kawabata, 2004).

Some plants form oxalic acid as an end products of metabolism (Massey, 2000).The different forms of oxalic acid are soluble and insoluble salts. Oxalic acid can form water-soluble by binding with ions of $\mathrm{K}^{+}, \mathrm{Na}^{+}$and $\mathrm{NH}_{4}{ }^{+}$, while insoluble oxalate is formed by chelating $\mathrm{Ca}^{++}, \mathrm{Fe}^{++}$and $\mathrm{Mg}^{++}$rendering these minerals unavailable(Savage et al., 2000).

It is worth to mention that the soluble oxalate is only absorbed in the digestive tract and rendering the minerals unavailable especially divalent metals ions such as calcium that can bind the oxalate anion. Notwithstanding, the insoluble oxalate is not absorbed and thereby excreted outside the body (Savage et al., 2000, Savage, 2002). So, regularly eating of oxalates rich diet can increase renal risk especially for susceptible individuals. This may be due to the formation of oxalate stones, which are crystals of calcium oxalate (Simpson et al., 2009).

Another anti-nutritional factor found in taro is phytic acid (phytate) that generally used to refer inositol hexaphosphoric acid or IP6. Phytic acid has affects many nutrients by limiting its bio-availability. It is well known that phytates form complexes with minerals (calcium, iron, zinc, copper and magnesium) and also with some proteolysis enzymes (pepsin and trypsin). Phytates are capable of forming complexes with amylases and chelating some minerals ions especially calcium which 
is an essential ion for enzymatic activity (Lan et al., 2018). Degradation of phytate to decrease the hazards associated with foods have high levels of phytate is one of the strategies that make minerals more bioavailable in the body (Schlemmer et al., 2009).

Reducing anti-nutritional factors may be achieved by processing methods such as peeling, washing, dicing, soaking blanching, drying and fermentations (Alcantara et al., 2013, Kumoroa et $a l ., 2014)$. Chemical strategy can be used to reduce soluble oxalate absorption from food by converting it into insoluble oxalate form. Numerous studies have demonstrated that soluble oxalate decreased in foods, when it consumed with food of high calcium level (Bong et al., 2017).

Calcium salts are widely accepted in food processing field. It can be used as firming agents, acidity regulators and stabilizers (Saltmarsh, 2013).

Although taro is widely growing in many parts of the world, it is underutilized crop and little is known about the anti-nutritional factors. The aim of this investigate was to study the effect of soaking in different concentrations of calcium salts on the content of soluble oxalate and phytic acid in fresh taro corm chips.

\section{MATERIALS AND METHODS}

\section{Materials:}

Fresh taro corms that used in the present study were obtained from the local market of Damanhur city, Egypt. Chemicals used were of analytical grade and bought from New Lab Com., Alexandria. Sodium salt of phytic acid (Sigma P-8810) was obtained from Sigma (Cairo, Egypt).

\section{Methods:}

\section{Sample preparation}

Fresh taro corms were washed and peeled by using stainless kitchen knife and all the unwanted parts were removed. Furthermore, taro corm chips with thickness $0.1 \mathrm{~cm}$ were obtained by using kitchen machine slicer (Braun, CombiMax 700). The chips samples were washed with cold water for 3 minutes to get rid of mucus on the surface and other materials attached water was drained off.

The ratio of taro corm chips to submerged solution was 1:4 (w/v). Addition of all calcium salts were carried out in triplicate at the following con- centrations $0,1,3$, or $5 \% \mathrm{w} / \mathrm{v}$. Three treatments were done using calcium carbonate, calcium chloride and calcium sulphate. Taro corm chips samples were soaked in solutions at different concentrations of calcium salts for 30 and 60 minutes. After each interval end time, the calcium salt solutions were drained off and allow the surface of samples to dry by exposure to the air for $20 \mathrm{~min}$.

\section{Dry matter and $\mathrm{pH}$}

Dry matter (DM) content was determined in triplicate by drying in an air oven until reaching constant weight as outlined in the AOAC, (2000). $\mathrm{pH}$ values of samples were measured by using a $\mathrm{pH}$ meter (Cyberscan $510 \mathrm{pH}$-meter) with the accuracy of \pm 0.01 according to the AOAC, (2000).

\section{Analysis of anti-nutritional factors}

\section{Total and soluble oxalate contents}

The contents of total oxalate and soluble oxalate in the fresh and treated samples were determined according to the procedure of Baker(1952) and all results are expressed as mg oxalate/100 g dry matter (DM). The content of insoluble oxalate (calcium oxalate) was calculated by difference (Holloway et al., 1989).

\section{Phytic Acid}

The phytate content was determined as described by Vaintraub \& Lapteva (1988) and the absorbance was measured using a spectrophotometer at $500 \mathrm{~nm}$. The results were presented as phytic acids in $\mathrm{mg} / 100 \mathrm{~g}(\mathrm{DM})$.

\section{Statistical Analysis:}

All analyses were carried out in triplicates. Data were analyzed using Two-way analysis of variance (ANOVA) models with calcium salts types, concentrations and their interactions to obtain analytical results using the Statistical Analysis System (SAS) Program (SAS Institute, Carey ,NC). Significance was determined at $P \leq 0.05$ level (SAS, 1999).

\section{RESULTS AND DISCUSSION}

\section{Dry matter and pH}

The content of dry matter for taro corm chips (untreated) was $25.15 \pm 0.37 \%$. These data are consistent with those reported by Sefa-Dedeh \&Agyir- Sackey (2004) and Savage \& Catherwood (2007). 
The data in Table (1) show the effect of soaking taro corm chips in solutions of calcium salts at different concentrations for $30 \mathrm{~min}$ on $\mathrm{pH}$ values. Significant difference could be traced among all types of calcium salts used as well the most concentrations of calcium salts. Also, it can be concluded that the $\mathrm{pH}$ values affected by incremental addition of calcium salts being slightly decreased except calcium carbonate which increased slightly to be 7.9 when using solution of 5\%. Similarly the data in Table (2) show the $\mathrm{pH}$ values of taro corm chips soaked for $60 \mathrm{~min}$ in solutions at different concentrations of calcium salts. The current data are in agreement with those of Bong, et al., (2017).

The $\mathrm{pH}$ values of taro chips were changed by soaking in solutions of different calcium salts; this may be due to the difference of solubility of calcium salts in water. Calcium chloride salt had the highest solubility followed by calcium sulphate and calcium carbonate that is in agreement with the reviewed results of Haynes \& Lide (2010).

\section{Effect of soaking time and concentrations of different types of calcium salts on soluble oxalate content}

The content of total, soluble and insoluble oxalate of untreated taro corm chips samples were 462.4, 294.3 and $168.1 \mathrm{mg} / 100 \mathrm{~g}$ DM, respectively. Nearly $63.65 \%$ of total oxalate content was in a form of soluble oxalate.

The contents of soluble oxalate for taro corm chips immersed in solutions with different levels of different calcium salts for 30 minute are presented in Table (3). The data revealed significant differences among all treatments.

Table 1: Effect of soaking taro corm chips in solutions of different calcium salts at for 30 minute on pH values.

\begin{tabular}{lcccc}
\hline $\begin{array}{c}\text { Concentration of } \\
\text { calcium salts (\%) }\end{array}$ & Calcium carbonate & Calcium chloride & Calcium sulphate & $\begin{array}{c}\text { Concentrations } \\
\text { (means) }\end{array}$ \\
\hline \multicolumn{5}{c}{$\mathbf{p H ~ v a l u e}$} \\
\hline 0 & $6.45 \pm 0.05^{\mathrm{d}^{*}}$ & $6.45 \pm 0.05^{\mathrm{d}}$ & $6.45 \pm 0.05^{\mathrm{d}}$ & $6.45^{\mathrm{C}}$ \\
1 & $6.75 \pm 0.05^{\mathrm{c}}$ & $6.35 \pm 0.05^{\mathrm{d}}$ & $6.45 \pm 0.05^{\mathrm{d}}$ & $6.52^{\mathrm{BC}}$ \\
3 & $7.50 \pm 0.10^{\mathrm{b}}$ & $6.10 \pm 0.10^{\mathrm{e}}$ & $6.35 \pm 0.05^{\mathrm{d}}$ & $6.65^{\mathrm{A}}$ \\
5 & $7.90 \pm 0.10^{\mathrm{a}}$ & $5.75 \pm 0.05^{\mathrm{f}}$ & $6.10 \pm 0.10^{\mathrm{e}}$ & $6.58 \mathrm{~A}^{\mathrm{B}}$ \\
Treatments(means) & $7.15^{\mathrm{A}}$ & $6.16^{\mathrm{C}}$ & $6.34^{\mathrm{B}}$ & \\
\hline
\end{tabular}

* Values followed by different capital letters within row or column are significantly different at $(P \leq 0.05)$ among calcium salts types and concentrations of $(0,1,3,5 \%)$ respectively, while values with different superscript small letters within all table show significant differences interaction at $(P \leq 0.05)$ among all treatments.

Each value was an average of three determinations \pm standard deviation.

Table 2: Effect of soaking taro corm chips in solutions of different calcium salts for 60 minute on pH values.

\begin{tabular}{lllll}
\hline $\begin{array}{c}\text { Concentration of cal- } \\
\text { cium salts (\%) }\end{array}$ & Calcium carbonate & Calcium chloride & Calcium sulphate & $\begin{array}{c}\text { Concentrations } \\
\text { (means) }\end{array}$ \\
\hline \multicolumn{5}{c}{$\mathbf{p H}$ value } \\
\hline 0 & $6.45 \pm 0.05^{\mathrm{d}}$ & $6.45 \pm 0.05^{\mathrm{d}}$ & $6.45 \pm 0.05^{\mathrm{d}}$ & $6.45^{\mathrm{B}}$ \\
1 & $7.55 \pm 0.05^{\mathrm{c}}$ & $6.20 \pm 0.10^{\mathrm{f}}$ & $6.35 \pm 0.05^{\mathrm{de}}$ & $6.70^{\mathrm{A}}$ \\
3 & $7.90 \pm 0.10^{\mathrm{b}}$ & $5.90 \pm 0.10^{\mathrm{g}}$ & $6.30 \pm 0.00^{\mathrm{ef}}$ & $6.70^{\mathrm{A}}$ \\
5 & $8.20 \pm 0.10^{\mathrm{a}}$ & $5.70 \pm 0.00^{\mathrm{h}}$ & $6.20 \pm 0.00^{\mathrm{f}}$ & $6.70^{\mathrm{A}}$ \\
Treatments (means) & $7.53^{\mathrm{A}}$ & $6.06^{\mathrm{C}}$ & $6.33^{\mathrm{B}}$ & \\
\hline
\end{tabular}

* Values followed by different capital letters within row or column are significantly different at $(P \leq 0.05)$ among calcium salts types and concentrations of $(0,1,3,5 \%)$ respectively, while values with different superscript small letters within all table show significant differences interaction at $(P \leq 0.05)$ among all treatments.

Each value was an average of three determinations \pm standard deviation. 
Table 3: Effect of soaking taro corm chips in solutions of different calcium salts at different concentrations for 30 minutes on soluble oxalate content $(\mathrm{mg} / 100 \mathrm{~g} \mathrm{DM})$.

\begin{tabular}{|c|c|c|c|c|}
\hline $\begin{array}{l}\text { Concentration of cal- } \\
\text { cium salts }(\%)\end{array}$ & Calcium carbonate & Calcium chloride & Calcium sulphate & $\begin{array}{l}\text { Concentrations } \\
\quad \text { (means) }\end{array}$ \\
\hline 0 & $291.6^{\mathrm{a}^{*}}$ & $291.6^{a}$ & $291.6^{\mathrm{a}}$ & $291.6 \mathrm{~A}$ \\
\hline 1 & $280.8^{\mathrm{b}}$ & $186.3^{\mathrm{e}}$ & $221.4^{\mathrm{c}}$ & $229.5 B$ \\
\hline 3 & $224.1^{c}$ & $70.2^{g}$ & $83.7^{f}$ & $126.0 \mathrm{C}$ \\
\hline 5 & $205.2^{\mathrm{d}}$ & $62.1^{\mathrm{h}}$ & $72.9 \mathrm{~g}$ & 113.4D \\
\hline Treatments (means) & $250.4 \mathrm{~A}$ & $152.6 \mathrm{C}$ & $167.4 \mathrm{~B}$ & \\
\hline
\end{tabular}

* Values followed by different capital letters within row or column are significantly different at $(P \leq 0.05)$ among calcium salts types and concentrations of $(0,1,3,5 \%)$ respectively, while values with different superscript small letters within all table show significant differences interaction at $(P \leq 0.05)$ among all treatments.

Each value was an average of three determinations \pm standard deviation.

It can be concluded that the content of soluble oxalate of soaked taro chips in water only for $30 \mathrm{~min}$ was minor decremented. This decrement may be due to leaching into the water, while increasing the concentrations of added calcium salts were more effective on decreasing soluble oxalate content.

The results in Table (4) reveal the effect of soaking taro corm chips in solutions of calcium salts at different concentrations for 60 minutes on soluble oxalate content. It can be observed that soluble oxalate content was significantly different among all treatments. Moreover, soaking in water only for 60 minute was effective to decrease about $5.5 \%$ of soluble oxalate content (294.3 to be 278.1 $\mathrm{mg} / 100 \mathrm{~g} \mathrm{DM}$ ). This result may be due to leaching into the water, while increasing the concentration of calcium salts had great effect. Calcium chloride helped to reduce the soluble oxalate content especially the concentration of 5\% that reduced the soluble oxalate content from 294.3 to $35.1 \mathrm{mg} / 100$ g (DM) $(88.07 \%)$, which may be converted to insoluble oxalate. Calcium carbonate had the lowest effect to decrease the content of soluble oxalate. This may be due to the lowest solubility of calcium carbonate in water. This observation is in accordance with Haynes \& Lide (2010).

The studies to reduce oxalate risk in taro corm by using different sources of calcium are scarce. However some studies have been conducted on spinach (Spinacia oleracea) (Brogren \& Savage, 2003, Bong, et al. 2017), raw taro leaves (Savage $\&$ Dubois, 2006).

On the other hand some studies have been conducted on the pre-treatment of taro corm to reduce the total oxalate content such as Sefa-Dedeh, \& Agyir-Sackey (2004) reported that the best processing to reduce total oxalate content in taro corm parts was the drying by drum dryer, that helped to reduce the oxalate content about $50 \%$. Kumoro, et al. (2014) found that the best condi-

Table 4: Effect of soaking taro corm chips in solutions of different calcium salts at different concentrations for 60 minutes on soluble oxalate content $(\mathrm{mg} / 100 \mathrm{~g}$ DM.

\begin{tabular}{lcccc}
\hline $\begin{array}{c}\text { Concentration of cal- } \\
\text { cium salts (\%) }\end{array}$ & Calcium carbonate & Calcium chloride & Calcium sulphate & $\begin{array}{c}\text { Concentrations } \\
\text { (means) }\end{array}$ \\
\hline 0 & & & & \\
$278.1 \mathrm{a}^{*}$ & $278.1 \mathrm{a}$ & $278.1 \mathrm{a}$ & $287.1 \mathrm{~A}$ & \\
1 & $256.5 \mathrm{~b}$ & $159.3 \mathrm{e}$ & $194.4 \mathrm{c}$ & $203.4 \mathrm{~B}$ \\
3 & $197.1 \mathrm{c}$ & $43.2 \mathrm{~g}$ & $54.0 \mathrm{f}$ & $98.1 \mathrm{C}$ \\
5 & $178.2 \mathrm{~d}$ & $35.1 \mathrm{~h}$ & $45.9 \mathrm{fg}$ & $86.4 \mathrm{D}$ \\
Treatments( means) & $227.5 \mathrm{~A}$ & $128.9 \mathrm{C}$ & $143.1 \mathrm{~B}$ & \\
\hline
\end{tabular}

* Values followed by different capital letters within row or column are significantly different at ( $\mathrm{P} \leq 0.05)$ among calcium salts types and concentrations of $(0,1,3,5 \%)$ respectively, while values with different superscript small letters within all table show significant differences interaction at $(\mathrm{P} \leq 0.05)$ among all treatments.

Each value was an average of three determinations \pm standard deviation. 
tions to reduce calcium oxalate content in taro root chips was the soaking in baking soda solution $10 \%$ for $2 \mathrm{hr}$ at ambient temperature. These results are not in agreement of data presented here this due to the different strategies used to decrease oxalate risk in taro corm. Accordingly, the determined oxalate forms were different.

The strategy of present study is depended on soaking in calcium salts solutions as source of calcium for short periods. This condition may convert soluble oxalate form to insoluble oxalate form (calcium oxalate). That strategy is accordance with (Savage et al., 2000, Savage, 2002) who reported that soluble oxalate is responsible for the formation of stones in the kidney, while insoluble oxalate (calcium oxalate) is not absorbed thereby excreted with faeces.

Also, the date of present study is in agreement with (Massey, et al. 2000) who found that minerals were became more available when soluble oxalate converted to insoluble form (calcium oxalate) as a function of inhibiting the chelating of minerals by the oxalate ion

\section{Effect of soaking time and concentrations of different types of calcium salts on phytic acid content}

Phytic acid content of raw taro chips was 161.16 (mg/100g DM). However, this result was in the ranges reported by Adane, et al. (2013) for raw taro in Ethiopia, and Huang, et al. (2007) for cultivars of taro grown in Taiwan. Generally, Kumar et al., (2005) concluded that the phytic acid contents differ according to the major factors that involved: variety, location, climatic, irrigation conditions, soil factors (e.g. $\mathrm{pH}$, soil temperature and status of organic phosphorus) and crop year.
The data presented in Table (5) show phytic acid content of tar o corm chips soaked for $30 \mathrm{~min}$ in solutions of different calcium salts. There was observed that no significant differences among all treatments except treatments with concentrations at $3 \%$ and $5 \%$ of calcium chloride salt. The present data are in accordance with the study of Lan, et al. (2018) who found that soaking Canadian pulses in distilled water for 4 hours at room temperature, markedly had no effect on phytic acid content. On the other hand, Patterson, et al . (2017) who reported that the soaking of pulses in water resulted in a marginally decreasing in phytates when they reviewed the effect of processing on a number of anti-nutritional factors in a range of pulses. This reduction might be depending on the elongation of soaking time.

The results of phytic acid content of taro corm chips soaked for $60 \mathrm{~min}$ in solutions of different calcium salts are given in Table (6). It was obvious that no significant differences could be traced among all salts examined here, with calcium chloride being the only exception. This was true for all concentration of the latter salt. The treatment of calcium chloride at concentration 5\% had the greatest effect. This treatment helped to decrease phytic acid content from 161.16 to $133.68 \mathrm{mg} / 100 \mathrm{~g}$ DM.

The current data are in agreement with those of Ford, et al. (1978) who concluded that by changing both the concentration of calcium chloride and the $\mathrm{pH}$ of soybean flour, phytic acid content decreased and mineral elements were more available. These results also revealed that phytic acid decreased to $10-90 \%$ and thereby zinc bioavailability increased from 10 to $90 \%$ and calcium concentration was doubled than that of original starting soybeans flour.

Table 5: Effect of soaking taro corm chips in solutions of different calcium salts for 30 minutes on phytic acid content (mg/100g DM).

\begin{tabular}{lcccc}
\hline $\begin{array}{c}\text { Concentration of } \\
\text { Calcium salts (\%) }\end{array}$ & Calcium carbonate & Calcium chloride & Calcium sulphate & Concentrations (mean) \\
\hline 0 & $160.96^{\mathrm{a}^{*}}$ & $160.96^{\mathrm{a}}$ & $160.96^{\mathrm{a}}$ & $160.96 \mathrm{~A}$ \\
1 & $160.92^{\mathrm{a}}$ & $159.44^{\mathrm{ab}}$ & $160.93^{\mathrm{a}}$ & $160.43 \mathrm{AB}$ \\
3 & $160.92^{\mathrm{a}}$ & $154.89^{\mathrm{b}}$ & $157.92^{\mathrm{ab}}$ & $157.91 \mathrm{~B}$ \\
5 & $160.91^{\mathrm{a}}$ & $144.28^{\mathrm{c}}$ & $156.41^{\mathrm{ab}}$ & $153.87 \mathrm{C}$ \\
Treatments (means) & $160.93 \mathrm{~A}$ & $154.89 \mathrm{C}$ & $159.05 \mathrm{~B}$ & \\
\hline
\end{tabular}

* Values followed by different capital letters within row or column are significantly different at $(P \leq 0.05)$ among calcium salts types and concentrations of $(0,1,3,5 \%)$ respectively, while values with different superscript small letters within all table show significant differences interaction at $(P \leq 0.05)$ among all treatments.

Each value was an average of three determinations \pm standard deviation. 
Table 6: Effect of soaking taro corm chips in solutions of different calcium salts for 60 minutes on phytic acid content (mg/100g DM).

\begin{tabular}{lcccc}
\hline $\begin{array}{c}\text { Concentration of } \\
\text { Calcium salts (\%) }\end{array}$ & Calcium carbonate & Calcium chloride & Calcium sulphate & $\begin{array}{c}\text { Concentrations } \\
\text { (means) }\end{array}$ \\
\hline 0 & $160.88^{\mathrm{a}^{*}}$ & $160.88^{\mathrm{a}}$ & $160.88^{\mathrm{a}}$ & $160.88 \mathrm{~A}$ \\
1 & $160.85^{\mathrm{a}}$ & $154.89^{\mathrm{b}}$ & $159.43^{\mathrm{ab}}$ & $159.39 \mathrm{AB}$ \\
3 & $160.85^{\mathrm{a}}$ & $148.83^{\mathrm{c}}$ & $159.32^{\mathrm{ab}}$ & $156.33 \mathrm{~B}$ \\
5 & $160.84^{\mathrm{a}}$ & $133.68^{\mathrm{d}}$ & $154.85^{\mathrm{b}}$ & $149.79 \mathrm{C}$ \\
Treatments (means) & $160.86 \mathrm{~A}$ & $149.57 \mathrm{C}$ & $158.62 \mathrm{~A}$ & \\
\hline
\end{tabular}

* Values followed by different capital letters within row or column are significantly different at $(P \leq 0.05)$ among calcium salts types and concentrations of $(0,1,3,5 \%)$ respectively, while values with different superscript small letters within all table show significant differences interaction at $(P \leq 0.05)$ among all treatments.

Each value was an average of three determinations \pm standard deviation.

Moreover, Han \& Anderson (1975) concluded that washing by using water or $1 \mathrm{~N} \mathrm{HCl}$ at temperature $25-50^{\circ} \mathrm{C}$ and $\mathrm{pH} 3.7-5.6$ and soaking time (1-4 hr) could easily remove more than $50 \%$ of phytic acid content in cottonseed and soybean. Moreover, it was also found that size particle of seed meals had minor impact on levels of phytate removed.

Using 5\% concentration of calcium chloride salt was more effective on decreasing phytic acid content. The reducing apparent in phytate level may be partly due either to phytate bound with other components or may be due to decrease the $\mathrm{pH}$ of taro corm chips that may activate internal phytase or degradation of phytic acid.

\section{CONCLUSION}

In conclusion, the present study suggests that to reduce the anti-nutritional factors of taro corm chips such as soluble oxalate and phytic acid, it should be soaked in calcium salts solutions. The soaking in calcium chloride solution $(5 \%)$ for 60 minutes had the greatest effect. So, this treatment is very important for decreasing expected kidney stones risks, also improving bioavailability of minerals in case of using taro chips as replacer for potato chips or for preparing instant infants foods.

\section{REFERENCE}

Adane, T., Shimelis, A., Negussie, R., Tilahun, B. \& Haki, G. 2013. Effect of processing method on the proximate composition, mineral content and antinutritional factors of taro (Colocasia esculenta, l.) grown in Ethiopia, African Journal of Food, 13: 7383- 7398.

Alcantara, R. M., Hurtada, W. A. \&Dizon, E
I. 2013. The nutritional value and phytochemical components of taro [Colocasia esculenta (L.) Schott] powder and its selected processed foods. Journal of Nutrition and Food Sciences, 3:1-7.

Association of Official Analytical Chemists (AOAC). 2000. Official methods of analysis of the association of official analytical chemists (17th Ed.). Washington, DC: 318 Association of Official Analytical Chemists

Baker, C. J. 1. 1952. The Determination of Oxalates in Fresh Plant Material. Analyst. 77: 34034

Bhandari, M. \& Kawabata, J. 2004. Assessment of antinutritional factors and bioavailability of calcium and Zinc in wild yam. Food Chemistry, 85: 281-287.

Bong, W., Leo P., Vanhanen, L.\& Savage, G. 2017. Addition of calcium compounds to reduce soluble oxalate in a high oxalate food system. Food Chemistry, $221: 54-57$.

Brogren, M., \& Savage, G. P. 2003. Bioavailability of soluble oxalate from spinach eaten with and without milk products. Asia Pacific Journal of Clinical Nutrition, 12: 219-224.

Ford, J. R., Mustakas, G.C., \& Schmuntz, R. D. 1978. Phytic acid removal from soybeans by lipid protein concentrate process. Journal of American oil chemistry society, 55: 371374.

Han, Y.W. \& Anderson, A.W. 1975. Semisolid fermentation of ryegrass straw. Applied Microbialogy, 30: 930-934.

Haynes, W. M., \& Lide, D. R. 2010. CRC handbook of chemistry and physics: A ready-reference 
book of chemical and physical data (91st ed.. Boca Raton, USA: CRC Press.

Holloway, W., Argall, M., Jealous, W., Lee, J. \& Bradbury, J. 1989. Organic acids and calcium oxalate in tropical root crops. Journal of Agricultural and Food Chemistry, 37: 337340.

Huang, C. C., Chen, W. C., \& Wang, C. C. 2007. Comparison of Taiwan paddy-and uplandcultivated taro (Colocasia esculenta L.) cultivars for nutritive values. Food Chemistry, 102, 250-256

John, J., Cho Roy, A., Yamakawa, R. \& J Hollyer, J. 2007. Hawaiian Kalo Past and future, Corporative Extension service, college of Tropical Agriculture and Human Nutrition, University of Hawaii at Manoa,p.

Kumar, V., Rani, A., Rajpal, S., Srivastava, G., Ramesh, A., \& Joshi, O. P. 2005. Phytic acid in Indian soybean: Genotypic variability and influence of growing location. Journal of the Science of Food and Agriculture, 85: 1523-1526.

Kumoroa, A.C., Putrib, A. R., Budiyatia, S. C. \& Retnowatia, S. D. 2014 . Kinetics of Calcium Oxalate Reduction in Taro (Colocasia esculenta) Corm Chips during Treatments Using Baking Soda Solution. Procedia Chemistry, 9: $102-112$.

Lan, S., Arntfielda, S.\& Nickersonb, M. 2018. Changes in levels of phytic acid, lectins and oxalates during soaking and cooking of Canadian pulses. Food Research International, 107: 660-668

Massey, L. 2000 . Tea oxalate. Nutrition Reviews, 58: $88-89$.

Matthews, P. 2004. Genetic diversity in taro, and the preservation of culinary knowledge. Ethnobotany Journal, 2: 55-77

Patterson, C. A., Curran, J., \& Der, T. 2017. Effect of processing on anti-nutrient compounds in pulses. Cereal Chemistry, 94: 2-10.
Saltmarsh, M. (ed.). 2013. Essential Guide to Food Additives (4th Ed.). Cambridge, GBR: Royal Society of Chemistry.

SAS Institute, Inc. 1999. PC-SAS users guide version 8. North Carolina: statistical analysis system institute, Inc.

Savage, G. P., Vanhanen, L., Mason S. L. \& Ross A. B. 2000. Effect of Cooking on the Soluble and Insoluble Oxalate Content of Some New Zealand Foods. Journal of Food Composition and Analysis, 13: 201- 206.

Savage, G. P. 2002. Oxalates in human foods. Proceedings of the nutrition society of new Zealand, 27: 4-24.

Savage ,G.P. \&Catherwood, D.J. 2007. Determination of oxalates in Japanese taro corms using an in vitro digestion assay. Food Chemistry, 105:383-388

Savage, G. P. \& Dubois, M. 2006. The effect of soaking and cooking on the oxalate content of taro leaves. International Journal of Food Science and Nutrition, 57: 376-381.

Schlemmer, U., Frølich, W. , Prieto R. \& Grases F. 2009. Phytate in foods and significance for humans: Food sources, intake, processing, bioavailability, protective role and analysis. Molecular Nutrition and Food Research, 53: S330 - S375.

Sefa-Dedeh, S. \& Agyir-Sackey, E. K. 2004. Chemical composition and the effect of processing on oxalate content of cocoyam Xanthosoma sagittifolium and Colocasia esculenta cormels. Food Chemistry, 85: 479-487.

Simpson, T. S., Savage, G. P., Sherlock, R., \& Vanhanen, L. P. 2009. Oxalate content of silver beet leaves (Beta vulgaris var. cicla) at different stages of maturation and the effect of cooking with different milk sources. Journal of Agricultural and Food Chemistry, 57: 10804-1080.

Vaintraub, I. \& Lapteva N. 1988. Colorimetric determination of phytate in unpurified extracts of seed and the products of their processing. Analytical Biochemistry, 17: 227-230. 


\title{
خفض محتوى رقائق القلقاس من الأكسالات الذائبة وحمض الفيتيك

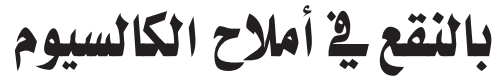

\section{سماء محمد صاح}

\author{
قسم الصناعات الغذائية - كلية الزراعة (ساباباشا) - جامعة الإسكندرية
}

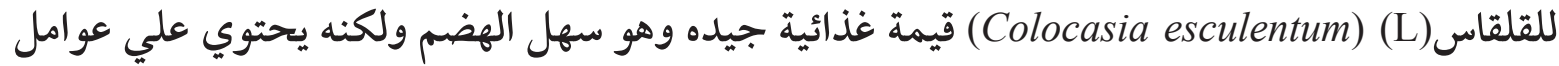

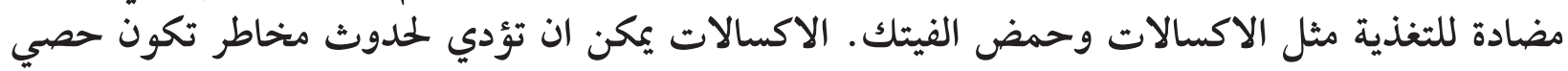

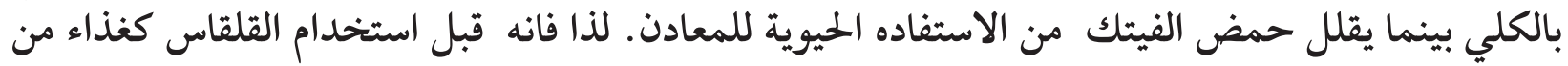

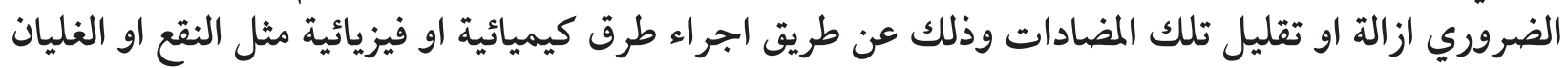

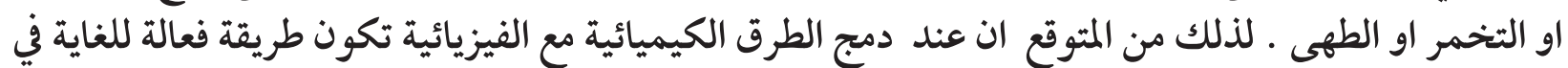

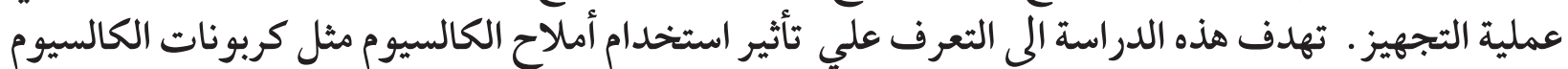

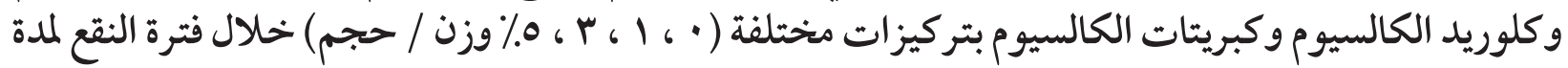

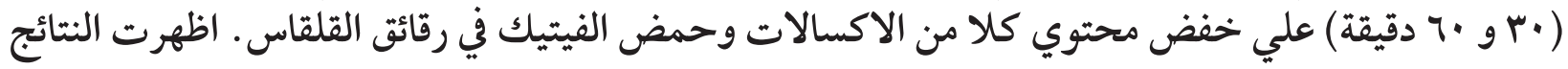

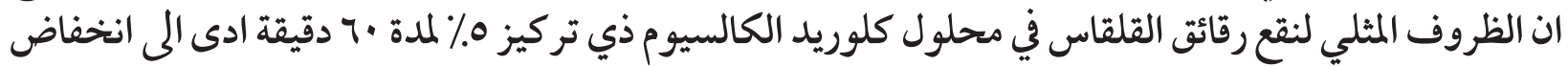

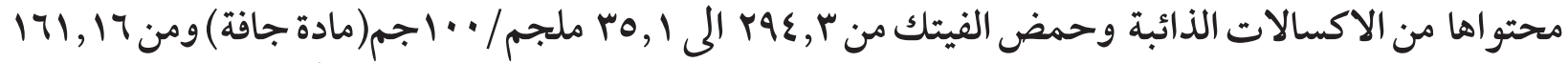

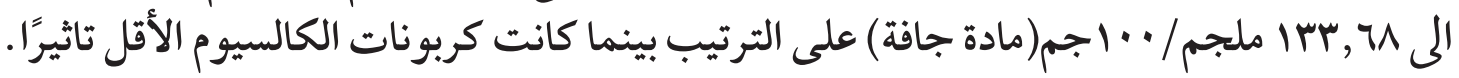

